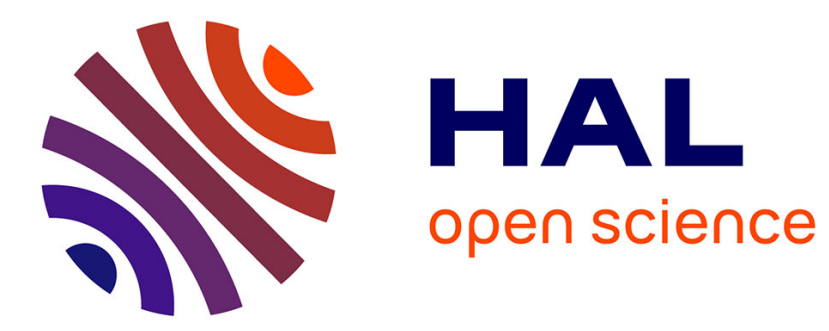

\title{
The Villefranche Strombidium sulcatum: A Review
}

\author{
John R. Dolan
}

\section{To cite this version:}

John R. Dolan. The Villefranche Strombidium sulcatum: A Review. European Journal of Protistology, 2018, 66 (Octobre 2018), pp.68-76. 10.1016/j.ejop.2018.08.002 . hal-02171958

\section{HAL Id: hal-02171958 \\ https://hal.sorbonne-universite.fr/hal-02171958}

Submitted on 9 Jul 2019

HAL is a multi-disciplinary open access archive for the deposit and dissemination of scientific research documents, whether they are published or not. The documents may come from teaching and research institutions in France or abroad, or from public or private research centers.
L'archive ouverte pluridisciplinaire HAL, est destinée au dépôt et à la diffusion de documents scientifiques de niveau recherche, publiés ou non, émanant des établissements d'enseignement et de recherche français ou étrangers, des laboratoires publics ou privés. 


\title{
The Villefranche Strombidium sulcatum: A Review
}

John R. Dolan

Sorbonne Université, UPMC Univ Paris 06, CNRS UMR 7093, Laboratoire

d'Océanographie de Villefranche-sur-Mer, Station Zoologique, Villefranche-sur-

Mer 06230, France

\begin{abstract}
The marine oligotrich ciliate Strombidium sulcatum, the best known marine oligotrich of the marine microozoplankton, was first cultured in Villefranche-surMer 35 years ago. Cultures were maintained from 1983 to 2003 and used in 22 studies investigating a very wide variety of questions. Here we review the major findings of these studies and underline their contributions to our knowledge of planktonic ciliate ecology and microbial ecology in general. We conclude with the observation that while ecophysiology has apparently fallen out of fashion, culture work will likely return as an invaluable resource in our present 'omics' era.
\end{abstract}

Keywords: model species; plankton; microzooplankton; culture; ecological physiology; oligotrich ciliate 


\section{Introduction}

The oligotrich ciliate Strombidium sulcatum has been the subject of many studies. A quick search in Google Scholar for publications containing the term "Strombidium sulcatum" yields over 500 titles. The species was described by Claparède and Lachmann from the Fjord of Bergen (Norway) in 1858 as the type species for the genus; it is then one of the longest-known oligotrich ciliates and is apparently cosmopolitan (Agatha 2011). It was subsequently found in the Bay of Kiel (Bütschli 1873). In the Mediterranean, it was found first in the Gulf of Naples by Entz (1884) and then in the port of Bastia in Corsica (Gourret \& Remus 1888). The first detailed observations made on S. sulcatum were by Fauré-Fremiet who examined cells from the marshes of Croisic, on the Atlantic coast of France (Fauré-Fremiet 1911; 1912). However, S. sulcatum was not brought into culture until 1983 when Dave Brownlee, working in Fereidoun Rassoulzadgan's lab, established cultures in Villefranche-sur-Mer. From 1983 to 2003, S. sulcatum was maintained in culture providing the raw material for the 22 laboratory studies reviewed here (for a complete chronological list please supplemental material).

The studies using the Villefranche culture of Strombidium sulcatum involved a quite large range of topics as indicated by the 'word cloud' in Figure 1 created from the titles of the publications. It should be noted firstly, that the species called $S$. sulcatum in the experiments reviewed here has been described as S. inclinatum (Montagnes et al. 1990; Granada \& Montagnes 2003). However, some researchers consider that $S$. sulcatum and S. inclinatum are likely synonymous (Song et al. 2000). Loss of all biological samples of S. sulcatum culture material prevents us from ever knowing with certainty the molecular identity of the ciliate cultured in Villefranche-sur-Mer. Secondly, while there have been many important studies using cultures of ciliates described as $S$. sulcatum isolated from other localities (e.g. Klein Breteler et al. 2004; Kiorboe 2009; Saiz et al. 2014; Chen et al. 2015; 2018), they are not considered here. Our goal in this review is to illustrate the myriad results that can be derived from a single ciliate culture.

Strombidium sulcatum is a heterotrophic oligotrich, about $40 \mu \mathrm{m}$ in length, and in the laboratory feeds on bacteria, small algae and heterotrophic 
nanoflagellates. In common with many free-living protists, it generally reproduces asexually via binary fission or cell division. Cyst production has not been reported but can not be excluded. Among oligotrich ciliates, the dividing cell develops a new mouth for the daughter cell and the original mouth does not degrade or become dis-organized thus the dividing cell continues to swim and possibly ingest prey while dividing. Basic morphological features and stages of cell division in S. sulcatum are shown in Figure 2.

The numerical response, changes in growth rate or rate of cell division as a function of food concentration, has been examined in Strombidium sulcatum. The numerical responses can be considered as the net result of feeding. Following Montagnes (2013), feeding and processing of food items can be broken down into individual steps. Here we will focus of the steps of swimming/encounter, prey capture, digestion and excretion because each of these steps has been examined in S. sulcatum in some detail. We will first briefly review, in sequence, knowledge about these steps based on work done using cultures of the Villefranche S. sulcatum, before consideration of the numerical responses. Following then the sections summarizing work on as S. sulcatum as prey consumer, nutrient recycler, and biomass producer, its role as prey for copepods will be reviewed. As stated above, our general goal is to summarize the rich results that have been obtained from a single ciliate culture but also specifically to point out that the considerable knowledge of S. sulcatum supports its use in establishing reference sequence databases in our 'omics' era.

\section{Swimming}

For a planktonic consumer, swimming rate and pattern largely determine the rate of encountering prey. Swimming in Strombidium sulcatum is characterized by movement in a helical pattern interrupted by occasional 'tumbles' resulting in a change of direction (Fenchel \& Jonsson 1982), as shown schematically in Figure 3. The average linear displacement is about $0.1 \mathrm{~cm} \mathrm{~s}^{-1}$, which translates into a possible distance travelled of about $100 \mathrm{~m}$ in 24 hours if the linear displacement was consistently in a single direction. Swimming speed and pattern can vary markedly. Tumbles increase in presence of aggregates of prey and results in the ciliate remaining near the prey (Fenchel \& Jonsonn 1988). 
In contrast,, ciliates that have been starved swim in a tight helical pattern, an apparently maladaptive behavior (Fenchel \& Jonsonn 1988). The study of Fenchel \& Jonsonn illucidated the mechanism behind ciliate chemotaxis and the variability in swimming behavior with physiological state. Later, a study examining the effects of small-scale turbulence found that swimming speeds might be lower when ciliates are subject to high levels of small-scale turbulence (such as in rough seas) resulting in lower ingestion and growth rates (Dolan et al. 2005).

\section{Prey Capture}

Feeding in Strombidium sulcatum, and other oligotrichs, involves first the capture of the prey item between the Collar Membranelles (see Fig. 2); then transport down into the Oral Cavity by the Buccal Membranelles where prey items are enclosed within a Food Vacuole within the ciliate cell for digestion. Prey size, relative to distances between membranelles, determines to a large extent the capture or not of a potential food item. In S. sulcatum the distance between the Collar Membranelles is about $2 \mu \mathrm{m}$ and between the Buccal Membranelles is about $0.5 \mu \mathrm{m}$ (Fenchel \& Jonsson 1988). When offered bacteria (both heterotrophic and the autotrophic Synechococcus and Prochlorococcus) and a variety of nano-flagellates, it feeds most efficiently on items $2-3 \mu \mathrm{m}$ in size, corresponding roughly to the distance between collar membranelles. Filtration rates are relatively low for both small bacteria and large nano-flagellates (Figure 4). However, filtration rates vary considerably among similar-sized bacteria and flagellates, indicating that capture also depends on factors other than size.

Investigations of the factors other than size which influence prey capture rates in Strombidium sulcatum have included considerations of the effects of the physiological state of the ciliate, the surface characteristics of the potential prey item, small-scale turbulence, and the presence small detrital particles. These factors were investigated in experiments using different types of microspheres. With regard to physiological state, rapidly growing log-phase, well-fed cells have higher filtration rates (about 30\%) compared to food-limited, stationary-phase ciliates (Christaki et al. 1998). Discrimination among prey items according to particle surface characteristics was also examined; plain microspheres were ingested at a rate about twice that of peptide-adsorbing carboxylate 
microspheres by both well-fed cells and food-limited cells (Christaki et al. 1998). Small-scale turbulence was found to have a negative effect on ingestion. Turbulence levels, roughly equivalent to that of a tidal front, resulted in lower ingestion rates in S. sulcatum (about 50\%) but did not effect discrimination against carboxylate microspheres compared to plain microspheres (Dolan et al. 2003). The presence of detrital particles, in the form of transparent exopolymer particles, also has a negative effect of ingestion rates in S. sulcatum (Mari \& Rassoulzadegan 2004). These studies largely contributed to our understanding of the mechanisms involved in selective feeding of microzooplankton. Interestingly, these investigations of $S$. sulcatum using microspheres have been also been used in recent years to argue that plastic pollution can enter the marine food web via ingestion by marine ciliates (Wright et al. 2013).

The effects of Strombidium sulcatum grazing on the bulk properties of seawater was investigated by examining changes in the optical characteristics of water containing Synechococcus with and subjected to grazing by S. sulcatum (Stramski et al. 1992). It was found the spectral shape of the scattering coefficient as well the spectral absorption coefficient of the cultures shifted with S. sulcatum grazing activity. The ingestion of algal prey by Strombidium sulcatum was investigated in the context of the dynamics of dimethysulfide and changes in the pools of DMSP between particulate and dissolved phases (Christake et al. 1996). When a DMSP-containing alga was subjected to grazing by S. sulcatum the release of dissolved DMSP was greatly increased.

Based on what we know of Strombidium sulcatum, we can roughly estimate the grazing impact of oligotrich ciliates. The maximum filtration rate estimate ( $\mu$ l per cell per hour) for S. sulcatum (Figure 4), if applied to all oligotrichs, can be used to calculate an aggregate oligotrich community filtration rate. This 'aggregate rate' can serve as an order of magnitude estimate of the potential impact of oligotrich grazing. In the Bay of Villefranche total oligotrich concentrations are usually about 1000 cells per liter (e.g., Ferrier-Pagés \& Rassoulzadegan 1994b; Mostajir et al. 1995) Applying a filtration rate of about 5 $\mu \mathrm{l}$ per hour per cell yields an aggregate estimate of about $120 \mathrm{ml}$ filtered by oligotrichs found in 1 liter or $12 \%$ of the water column filtered per day by oligotrich ciliates in the Bay of Villefranche. 


\section{Digestion}

The effects of both temperature and food type on digestion in Strombidium sulcatum have been investigated. The digestion rate of bacteria (or more precisely their rate of apparent disappearance) increases with temperature over a range of $12-22^{\circ} \mathrm{C}$ with a $Q_{10}$ of about 2 (Sherr et al. 1988). At a given temperature, digestion rate appears to be an exponential decay rate in $S$. sulcatum. Correspondence with a decay rate, rather than a fixed passage time, reflects the fact that in ciliates, food vacuoles are not processed in a strict 'first in, first out' order. Digestion rates of S. sulcatum fed live or heat-killed prey of different sizes was found to be similar, as were digestion rates of feeding cells and those held in particle-free water. This latter finding indicates that processing of food vacuoles appears to be independent of feeding activity rate. Furthermore, the digestion rates for algal prey were similar to inert microsphere 'residence time', time from ingestion to excretion (Dolan \& Simek 1997). Thus, $S$. sulcatum appears to process similarly all ingested items. The estimated half-life of an ingested item in S. sulcatum is 75 minutes at $22{ }^{\circ} \mathrm{C}$. The digestion studies indicated that ingestion rates of natural population could be estimated given knowledge of digestion time (as it appears to be constant at a given temperature) and food vacuole contents.

\section{Excretion}

The first investigations of excretion in Strombidium sulcatum were made using ciliate cultures held in dialysis membrane bags, allowing ciliate excretory products to diffuse out into surrounding waters. Samples of natural plankton from the Bay of Villefranche were incubated with the ciliate cultures held in dialysis bags to examine effects on natural populations of plankton. The experiments showed that exposure to ciliate cultures increased growth rates of some populations in proportion to the concentration of ciliates held in the dialysis membrane bags. Growth rates increased for bacteria, cyanobacteria, autotrophic picoflagellates and autotrophic nanoflagellates but not the larger phytoplankton taxa (Ferrier \& Rassoulzadegan 1991). Subsequently, per cell 
rates of nitrogen and phosphorus regeneration of $S$. sulcatum were estimated using ciliate cultures fed only heat-killed bacteria to avoid artifacts due to prey excretion or absorption of regenerated matter. Nitrogen excretion rates were estimated to be $0.25-2 \mu \mathrm{g}$ N per mg dry weight per h (Ferrier-Pages \& Rassoulzadegan 1994a) and phosphorus 0-24.6 $\mu \mathrm{g}$ P per mg dry weight per $\mathrm{h}$ (Allali et al. 1994). The experiment showed that, as one might expect based on known allometric relationships, the weight-specific excretion rates of $S$. sulcatum are high compared to larger planktonic organisms. However, S. sulcatum phosphorus excretion increases with growth rate, in contrast to nitrogen excretion, as ammonia (Fig. 5). Furthermore, excretion rates of phosphorus relative to nitrogen may exceed the Redfield ratio of 16:1 (Fig. 6) suggesting a more important role in regeneration of phosphorus compared to nitrogen, as is the case with many planktonic protists (Dolan 1997.) However it is worth noting that nitrogen is possibly excreted in significant quantities in forms other than ammonia such as dissolved amino acids by S. sulcatum (Ferrier-Pages et al. 1997).

In other experiments examining phosphate transfer between microbial size fractions using ${ }^{32} \mathrm{P}$ labeling, the addition of $S$. sulcatum to natural communities yielded declines in the particulate and increases in the inorganic fractions of phosphorus, again suggesting that $S$. sulcatum is an efficient phosphorus regenerator (Dolan et al. 1995). Overall, the studies clearly showed that oligotrich ciliates, as grazers on pico and nano-plankton, do likely act as important regenerators of nutrients as postulated by Johannes (1964). For example, Ferrier \& Rassoulzadegan (1994) in extrapolating nitrogen regenerations measured for $S$. sulcatum to natural populations of planktonic ciliates in the Mediterranean Sea concluded that ciliates could account for about $25 \%$ of total nitrogen regeneration.

\section{Numerical Response}

The numerical response, in formal terms, is the change in predator density as a function of prey density, for example as seen in predator-prey cycles. With regard to Strombidium sulcatum (and other protists which feed) it is equivalent to the changes in cell division rate as a function of prey concentration. 
This has been examined in S. sulcatum feeding on bacteria and feeding on a heterotrophic nanoflagellate. Growth rates of up to 3 generations per day at $15^{\circ} \mathrm{C}$ were recorded for ciliates grown in relatively dense solutions of bacteria $\left(10^{7}\right.$ $10^{8}$ cells $\mathrm{ml}^{-1}$ ) by Rivier et al. (1985). Growths of S. sulcatum in lower concentrations of bacteria, and growth on a heterotrophic nanoflagellate, were examined by Fenchel \& Jonsonn (1988). In cultures grown at $20^{\circ} \mathrm{C}$, the cell division rates, as function of prey concentration, reached a maximum of about 3 generations per day for both prey items. For S. sulcatum fed bacteria, the prey concentrations yielding about half the maximum growth rate ( 1.5 generations per day) was about $1 \times 10^{6}$ bacteria per $\mathrm{ml}$ while for ciliates fed the nanoflagellate, the concentration yielding 1.5 generations per day was about $5 \mathrm{x}$ $10^{3}$ cells per ml (Fig. 6). These latter concentrations of bacteria and nanoflagelllates are well within the range recorded for the Bay of Villefranche (e.g. Mostajir et al. 1995). Notably, similar maximum growth rates of about 3 generations per day are also possible when S. sulcatum is fed the autotrophic prokaryotes Synechococcus or Prochlorococcus, albeit in the presence of very high prey concentrations (Christaki et al. 1999). Hence rapid growth of $S$. sulcatum is possible with a variety of diets.

Survival in the absence of prey was examined by Fenchel \& Jonsson (1988). They reported low mortality rates in the first 50 hours of starvation followed by high mortality resulting in a 10\% survival rate after 80 hours of starvation. To our knowledge there are no data available concerning the process of recovery from a starvation state in Strombidium sulcatum.

Given knowledge of both the growth rate, and the ingestion rate, biomass conversion efficiency (also known as trophic transfer rate) can be calculated. Over the range of prey concentrations they examined, Fenchel and Jonsonn (1988) found that the number of bacterium ingested, or nanoflagellates ingested, corresponding with the production of one new ciliate was constant. They reported constant biomass conversion efficiency for Strombidium sulcatum of about $50 \%$ and described the figure as common for heterotrophic protists. The studies with S. sulcatum showed that pico and nano-planktonic biomass could be 
efficiently re-packaged as ciliate biomass available for consumption by higher trophic levels.

\section{Consumption by copepods}

The major predators of microzooplankton are thought to be copepods. Ciliates, in particular have long been known to be consumed by a wide variety of copepods (e.g. Heinle et al. 1977; Berk et al. 1977). As a 'model planktonic ciliate' Strombidium sulcatum has been used in many investigations with copepods as predators. The studies using cultures of $S$. sulcatum isolated from the Bay of Villefranche have focused on diverse topics ranging from studies of prey selection in different species of copepods (Wiadnyana \& Rassoulzadegan 1989), as prey in studies examining the effects of turbulence on copepod feeding behaviour (Caparroy et al. 1998) and as a food item in attempts to quantify the nutritional value of ciliates, relative to phytoplankton, as food items for copepods (Bonnet \& Carlotti 2001).

The first study examined selective feeding. The copepods Acartia clausi and Centropages typicus when offered S. sulcatum with a similar-sized diatom or dinoflagellate fed at much higher rates on S. sulcatum (Wiadnyyana \& Rassoulzadgan 1989). As the authors pointed out, the fact that the copepods readily preyed on $S$. sulcatum showed that planktonic ciliates, as consumers of microbes, could provide the trophic link between the microbial populations and higher trophic levels. The answer was provided to the question (at that time) of the microbial loop serving as a carbon sink or a link to higher trophic levels for dissolved organic carbon (e.g. Gasol \& Kirchman 2018).

In the second study, the considerable complexity of copepod predation on ciliates was exposed. Caparroy et al. (1998) investigated of the effects of smallscale turbulence on $C$. typicus feeding on S. sulcatum. Firstly, a qualitative change in the swimming behavior of the copepod was found comparing the presence and absence of S. sulcatum. Secondly, intermediate levels of turbulence, similar to those which were later found to be detrimental to $S$. sulcatum growth (Dolan et al. 2003), increased copepod clearance rate by a factor of 4, a much higher difference than that known from species of Acartia. The third study compared developmental time and egg production rates of $C$. typicus raised on algal diets 
with and without S. sulcatum (Bonnet \& Carlotti 2001). The optimum diet for development and egg production were the mixed diets including S. sulcatum showing the value to the copepod of ingesting oligotrich ciliates.

\section{Strombidium sulcatum-size oligotrichs in natural ciliate asemblages}

To our knowledge there is no quantitative data on Strombidium sulcatum in natural assemblages. Studies of the composition and dynamics of planktonic ciliates nearly always are based on examinations, using an inverted microscope, of Lugol's-fixed water samples, which does not allow reliable species identification (Agatha 2011). However, data on the occurrence and variability of oligotrich ciliates in various size-classes does exist for the Bay of Villefranche. In these studies, $S$. sulcatum-type cells would be classed among medium-sized oligotrichs (i.e., lugol's-fixed cells of 30-50 $\mu \mathrm{m}$ in length). In surface waters of the Bay of Villefranche, small oligotrichs $(<30 \mu \mathrm{m})$, medium oligotrichs $(30-50 \mu \mathrm{m})$ and large oligotrichs ( $>50 \mu \mathrm{m})$ co-vary closely and are found in average concentrations of about 300 cells per liter for cells in each size-class, with peaks in February of 2000 cells liter and minimal concentrations in late December (Rassoulzadegan 1977). Hence, S. sulcatum-size oligotrichs appear to representative of the planktonic ciliate assemblage with regard to average abundance and seasonal variability.

The growth rates of Strombidium sulcatum estimated in the laboratory experiments reviewed here appear to be appear to be similar to rates estimated for other similar-sized oligotrichs in laboratory experiments as well those estimated in field experiments, corrected for temperature (Perez et al. 1997). Likewise, the filtration rates of copepods feeding on S. sulcatum appear similar to other reports of copepods feeding on oligotrich ciliates but reported filtration rates appear to often vary by over an order of magnitude (Perez et al. 1997). Overall, the data derived from studies of the Villefranche S. sulcatum appear to be representative and justify entitle it to be called a 'model marine oligotrich'.

\section{Conclusions and perspectives}

The culture started by Dave Brownlee provided the material exploited by a large number of people who produced a respectable number of papers at a relatively 
steady rate over nearly 2 decades (Fig. 7). The papers cumulatively have garnered over 1,500 citations and many are still regularly cited today.

The end of the culture in 2003 was due to an unnoticed incubator failure (in those days our incubators had no alarm signals). By the early 2000's, In Villefranche the foci of research had shifted (as in most other laboratories of biological oceanography) from ecophysiology of particular planktonic taxa to fluxes of nutrients and carbon, dynamics of prokaryote populations, and biodiversity. Thus, there was little impetus to re-establish the culture. Indeed still today the priorities of the funding institutions rarely include ecophysiolgy except for taxa of direct societal concern (e.g. toxic algae). It is perhaps then not surprising that work done in recent years with 'other' (not Villefranche) cultures of Strombidium sulcatum laboratories in Spain, Denmark, Germany and China displays an apparent distinct shift in focus compared to earlier work with Villefranche S. sulcatum. Figure 8, is a word cloud from the titles of papers reporting use of $S$. sulcatum cultures, those published from 2009-2018. The difference with the word cloud of older titles of Fig. 1 are most notably the much lower frequency of the words 'ciliate' and 'marine' in the titles as well as the appearance of molecular terms.

Interest in estimating physiological rates of planktonic ciliates appears to have faded. Going forward, it should be noted that there is growing recognition of the actual importance the complexity found in the microzooplankton (longknown- e.g., reviewed in Conover 1982). For example, the diversity and commonness of mixotrophy (Stoecker et al. 2017). This brings with it the realization that there likely is no single representative taxon, thus Strombidium sulcatum is perhaps at best a 'model species' for a single type of oligotrich.

On the other hand, while we know the plankton is characterized by a complexity of relationships and plasticity in trophic modes, nonetheless computer simulations of planktonic communities employing relatively few and strictly defined functional groups resembling 'model taxa' (e.g., bacteria, bacteriovores, small and large phytoplankton, small and large zooplankton) can successfully mimic observed patterns of abundance in the North Atlantic (e.g., Taylor et al. 1993) and global geographic distribution (Stock et al. 2014). The utility of such simplifying models suggests that assigning major or dominant 
functions (e.g., primary producer, consumer) based on data from some taxa to likely reflects reality. Also noteworthy is the fact that the advent of metatranscriptomics and metaprotemeomics is renewing recognition of the vital importance of culture-based studies (Morris 2018). Current efforts directed at environmental sequencing are severely hampered by an ignorance of the identity and function of many transcripts and proteins. Only culture work allows direct linkage of genes and the products of their expression (e.g., Rappé 2013). Thus there is need for molecular studies of both well-known species such as $\mathrm{S}$. sulcatum and both ecophysiological as well as molecular studies of a variety of taxa to exploit to understand environmental sequence data.

\section{Acknowledgements}

This work was supported by the Centre National de la Recherche Scientifique and Sorbonne Universite, Université Pierre et Marie Curie, Paris VI.

\section{References}

Agatha, S., 2011. Global diversity of aloricate Oligotrichea (Protista, Ciliophora, Spirotricha) in marine and brackish sea water. PloS One, 6(8), e22466.

Allali, K., Dolan, J., \& Rassoulzadegan, F., 1994. Culture characteristics and orthophosphate excretion of a marine oligotrich ciliate, Strombidium sulcatum, fed heat-killed bacteria. Mar. Ecol. Prog. Ser., 105, 159-165.

Bernard, C., \& Rassoulzadegan, F., 1990. Bacteria or microflagellates as a major food source for marine ciliates: possible implications for the microzooplankton. Mar. Ecol. Prog. Ser., 64, 147-155.

Bonnet, D., Carlotti, F., 2001. Development and egg production in Centropages typicus (Copepoda: Calanoida) fed different food types: a laboratory study. Mar. Ecol. Prog. Ser., 224, 133-148 
Bütschli, 0., 1873. Einiges über infusorien. Arch. Mikros. Anat, 9, 657-678.

Claparède, É., Lachmann J., 1858 Études sur les infusoires et les rhizopodes. Mém. Instit. Nat. Genev., 5, 1-260.

Caparroy, P., Pérez, M. T., Carlotti, F., 1998. Feeding behaviour of Centropages typicus in calm and turbulent conditions. Mar. Ecol. Prog. Seri., 168, 109-118.

Chen, X., Zhao, X., Liu, X., Warren, A., Zhao, F., Miao, M., 2015. Phylogenomics of non-model ciliates based on transcriptomic analyses. Protein Cell, 6, 373-385.

Christaki, U., Belviso, S., Dolan, J. R., Corn, M., 1996. Assessment of the role of planktonic copepods and ciliates in the release to solution of DMSP in the N. W. Mediterranean Sea. Mar. Ecol. Prog. Ser. 141, 119-127.

Christaki, U., Dolan, J. R., Pelegri, S., Rassoulzadegan, F., 1998. Consumption of picoplankton-size particles by marine ciliates: Effects of physiological state of the ciliate and particle quality. Limnol. Oceanogr., 43, 458-464.

Christaki, U., Jacquet, S., Dolan, J. R., Vaulot, D., \& Rassoulzadegan, F., 1999. Growth and grazing on Prochlorococcus and Synechococcus by two marine ciliates. Limnol. Oceanogr., 44, 52-61.

Conover, R.J. 1982. Interrelationships between microzooplankton and other plankton organisms. Ann. Inst. Océanogr., Paris 58 (Suppl): 31-46.

Dolan, J. R ., Simek, K., 1997. Processing of ingested matter in Strombidium sulcatum, a marine ciliate. Limnol Oceanogr., 42,393-397.

Dolan, J. R., Thingstad, T. F., Rassoulzadegan, F., 1995. Phosphate transfer between microbial size-fractions in Villefranche Bay (NW Mediterranean Sea), France in autumn 1992. Ophelia, 41, 71-85. 
Dolan J. R., Sall N., Metcalfe A., Gasser B., 2003. Effects of turbulence on feeding and growth in a marine oligotrich ciliate. Aquat. Microb. Ecol. 31, 183-192.

Entz, G., Sr., 1884. Über Infusorien des Golfes von Neapel. Mittheilung. Zool. Stat. Neapel, 5, 289-444.

Fauré-Fremiet, E., 1911. Sur le mode de division du Strombidium sulcatum Cl. et Lach. Bull. Soc. Zool. France, 36, 207-208.

Fauré-Fremiet, E., 1912. Études cytologiques sur quelques infusoires des marais salants du Croisic. Arch. Anat. Microsc, 13, 401-479.

Fenchel, T., Jonsson, P.R., 1988. The functional biology of Strombidium sulcatum, a marine oligotrich ciliate (Ciliophora, Oligotrichina). Mar. Ecol. Prog. Ser., 48, 115.

Ferrier, C., Rassoulzadegan, F., 1991. Density-dependent effects of protozoans on specific growth rates in pico- and nanoplanktonic assemblages. Limnol Oceanogr., 36, 657-669.

Ferrier-Pages, C., Rassoulzadegan F., 1994a. N remineralization in planktonic protozoa. Limnol. Oceanogr., 39, 411-419.

Ferrier-Pages, C., Rassoulzadegan, F. (1994b). Seasonal impact of the microzooplankton on pico-and nanoplankton growth rates in the northwest Mediterranean Sea. Mar. Ecol. Prog. Ser., 108: 283-283.

Ferrier-Pagès, C., Karner, M., Rassoulzadegan, F., 1998. Release of dissolved amino acids by flagellates and ciliates grazing on bacteria. Oceanol. Acta, 21, 485494. 
Gasol, J.M., Kirchman, D.L., 2018. Introduction: the evolution of microbial ecology of the ocean. In: Gasol, J.M. , Kirchman, D.L. (eds.), Microbial Ecology of the Ocean,Wiley, Hoboken N.J., pp 1-46.

Gourret, P., \& Roeser, P. (1888). Contribution à l'étude des protozoaires de la Corse. Arch. Biol, 8, 139-204.

Granda, A. P., Montagnes, D.J. S., 2003. An improved description of Strombidium sulcatum Claparéde \& Lachmann, 1859 (Ciliophora) from slides of Fauré Fremiet, and a designation of type material. J. Euk. Microbiol., 50, 422-426.

Klein Breteler, W. C. M., Koski, M., Rampen, S. (2004). Role of essential lipids in copepod nutrition: no evidence for trophic upgrading of food quality by a marine ciliate. Mar. Ecol. Prog. Ser., 274, 199-208.

Kiørboe, T., Andersen, A., Langlois, V. J., Jakobsen, H. H., Bohr, T., 2009.

Mechanisms and feasibility of prey capture in ambush-feeding zooplankton. Proc. Nat. Acad. Sci. USA, 106, 12394-12399.

Mari, X., Rassoulzadegan, F., 2004. Role of TEP in the microbial food web structure. I. Grazing behavior of a bacterivorous pelagic ciliate. Mar. Ecol. Prog. Ser., 279, 13-22.

Montagnes, D.J.S., 2013. Ecophysiology and behaviour of tintinnids. In: Dolan, J.R., Montagnes, D.JS., Agatha, S., Coats, D.W., Stoecker, D.K. (eds.) The Biology and Ecology of Tintinnid Ciliates: Models for Marine Plankton, Wiley-Blackwell, Oxford, pp 17-41.

Montagnes, D.J.S., Taylor, F.J.R., Lynn, D.H., (1990) Strombidium inclinatum n. sp. and a reassessment of Strombidium sulcatum Claparède and Lachmann (Ciliophora). J. Protozool., 37, 318-323. 
Morris, R.M., 2018. Metatranscriptomics: elucidating marine microbial ecosystem functions. In: Gasol, J.M. , Kirchman, D.L. (eds.), Microbial Ecology of the Ocean, Wiley, Hoboken N.J., pp 123-147.

Mostajir, B., Dolan, J. R., Rassoulzadegan, F. (1995). Seasonal variations of picoand nano-detrital particles (DAPI Yellow Particles, DYP) in the Ligurian Sea (NW Mediterranean). Aquat. Microb. Ecol., 9: 267-277.

Rappé, M.S., 2013. Stabilizing the foundation of the house that omics builds: The evolving value of cultured isolates to marine microbiology. Curr. Opin. Microbiol. $16,618-624$.

Rassoulzadegan, F., 1977. Evolution annuelle des ciliés pélagiques en Méditerranée Nord-Occidentale ciliés oligotriches 'non tintinnides' (Oligotrichina). Ann. Inst. Océanogr., Paris, 53, 125-134.

Rivier, A., Brownlee, D.C., Sheldon, R.W., Rassoulzadegan, F., 1985. Growth of microzooplankton: A comparative study of bactivorous zooflagellates and ciliates. Mar. Microb. Food Webs., 1, 51-60.

Saiz, E., Griffell, K., Calbet, A., Isari, S., 2014. Feeding rates and prey: predator size ratios of the nauplii and adult females of the marine cyclopoid copepod Oithona davisae. Limnol. Oceanogr., 59, 2077-2088.

Sherr, B. F., Sherr, E. B., Rassoulzadegan, F., 1988. Rates of digestion of bacteria by marine phagotrophic protozoa: temperature dependence. Appl. Environ. Microbiol., 54, 1091-1095.

Song, W., Wang, M., Warren, A. 2000. Redescriptions of three marine ciliates, Strombidium elegans Florentin, 1901, Strombidium sulcatum Claparede \& Lachmann, 1859 and Heterostrombidium paracalkinsi Lei, Xu \& Song, 1999 (Ciliophora, Oligotrichida). Eur. J. Protistol., 36, 327-342. 
Stock, C.A., Dunne, J.P., John, J.G. (2014.)Global-scale carbon and energy flows through the marine planktonic food web: An analysis with a coupled physicalbiological model. Prog. Oceanogr., 120:1-28.

Stoecker, D. K., Hansen, P. J., Caron, D. A., Mitra, A. (2017). Mixotrophy in the marine plankton. Ann. Rev. Mar. Sci. 9: 311-335.

Stramski, D., Rassoulzadegan, F., Kiefer, D.A., (1992). Changes in the optical properties of a particle suspension caused by protist grazing. J. Plankton Res., 14, 961-977.

Taylor, A.H., Harbour, D.S., Harris, R.P., Burkill, P.H., Edwards. E.S., (1993) Seasonal succession in the pelagic ecosystem of the North Atlantic and the utilization of nitrogen, J. Plank. Res., 15:875-891.

Wiadnyana, N. W., Rassoulzadegan, F. 1989. Selective feeding of Acartia clausi and Centropages typicus on microzooplankton. Mar. Ecol. Prog. Ser., 53, 37-45. 
Figure Legends

Fig. 1. Word cloud made of the 75 most frequently occurring words in the titles of the 22 publications, which appeared between 1985 and 2004, reporting work done using the Villefranche culture of Strombidium sulcatum. The size of a word reflects its relative frequency of occurrence. The complete list of publications is provided in the supplementary material.

Fig. 2. Gross anatomy and cell division stages of Strombidium sulcatum. Beating of the Collar Membranelles (CM) moves the cell and brings potential food items to the Buccal Membranelles for transport into the Oral Cavity (OC). In the Oral Cavity ingested food items are enveloped inside Food Vacuoles (FV) inside which digestion occurs within the ciliate cell. The Macronucleus (MN) is the somatic nucleus and the Micronucleus (MN) contains chromosomes replicated during sexual reproduction. During asexual cell division, the Daughter Cell Mouth (DCM) develops in the anterior portion of the cell; the mouth of the parental cell remains functional. The Macronucleus is partitioned between the two cells. In the late division stage the two mouths are functional shortly before cell separation. Adapted from Faure-Fremiet 1912.

Fig. 3. Schematic representation of swimming in Strombidium sulcatum based on Fenchel \& Jonsonn 1988. Well-fed ciliates swim in a roughly helical pattern with periodic 'tumbles' potentially resulting in a change of direction (shown as multiheaded arrows); in 1 second the ciliate travels the straight-line equivalent of about $1 \mathrm{~mm}$. When starved 24-48 h, the ciliate swims in a tight helical path with few if any tumbles.

Fig. 4. The relationship between prey size and capture efficiency (as indicated by maximum filtration rate) of Strombidium sulcatum fed different sized bacteria and nano-flagellates. Data from Fenchel \& Jonsonn 1988; Bernard \& Rassoulzadegan 1990; Christaki et al. 1999.

Fig. 5. Cell-specific excretions rates of nitrogen (measured as ammonia) and phosphorus (measured as orthophosphate) as a function of growth rate in 
Strombidium sulcatum fed heat-killed bacteria. Note that 1) excretion of phosphorus increases with growth rate in contrast to nitrogen and 2) for cells growing at moderate rates ( $>1$ generation per day), phosphorus excretion relative to nitrogen exceeds the Redfield ratio. Nitrogen excretion data from Ferrier \& Rassoulzadegan 1994 and phosphorus excretion data from Allali et al. 1994.

Fig. 6. Examples of the numerical response of Strombidium sulcatum. Note that maximum growth rates of about 3 generations per day were found for ciliates feeding on bacteria and also those feeding on a heterotrophic nanoflagellate. Data from Fenchel \& Jonsonn (1988).

Fig. 7. The number of articles published by year reporting work done with the Villefranche Strombidium sulcatum cultures.

Fig. 8. Word cloud made of the 75 most frequently occurring words in the titles of the 9 publications, which appeared between 2009 and 2017, reporting work done using cultures of Strombidium sulcatum. The size of a word reflects its relative frequency of occurrence. The list of publications is provided in the supplementary material. See Fig. 1 for a comparison with earlier work using the Villefranche cultures. 


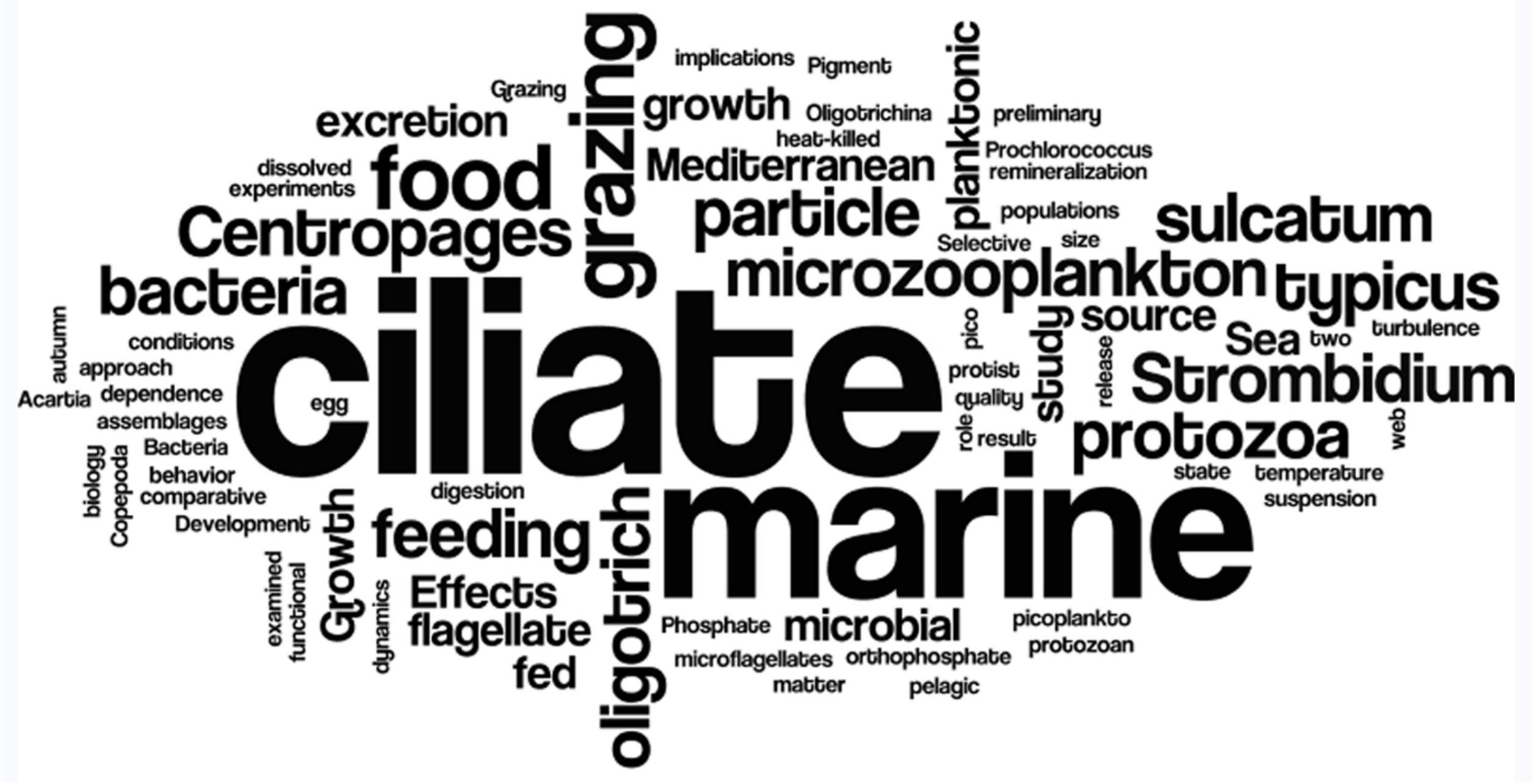

Fig 1 


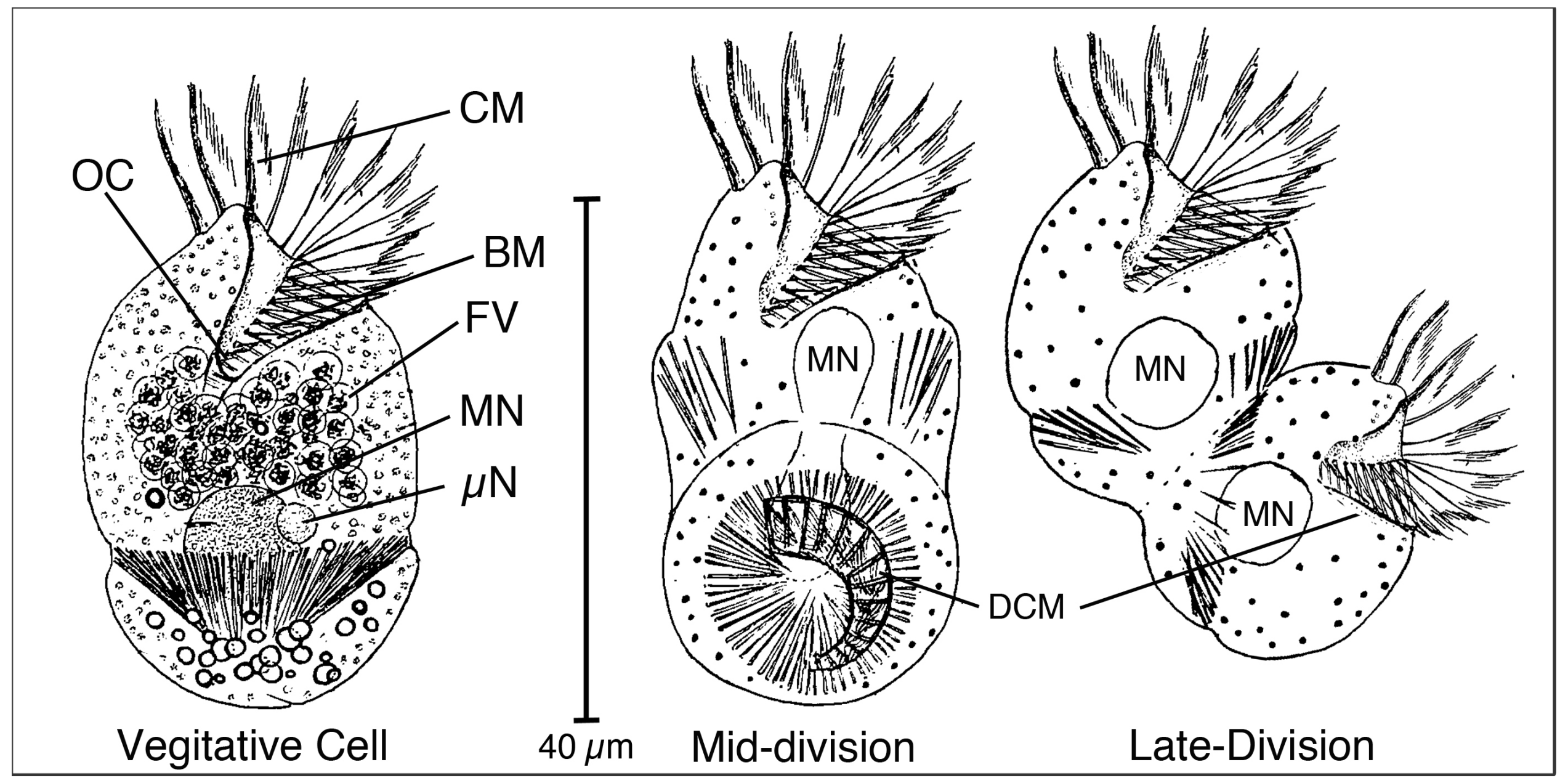

Fig 2 


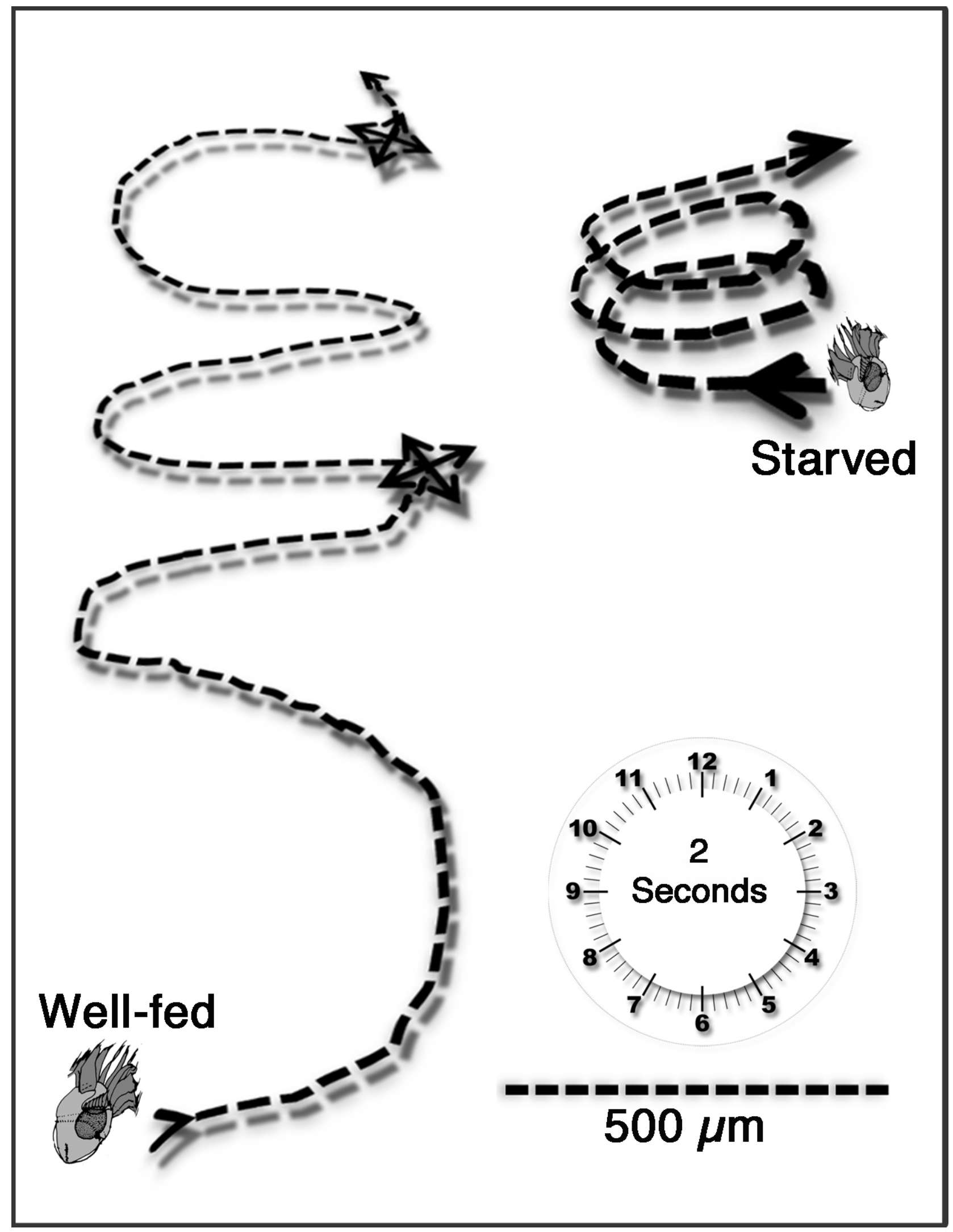

Fig 3 


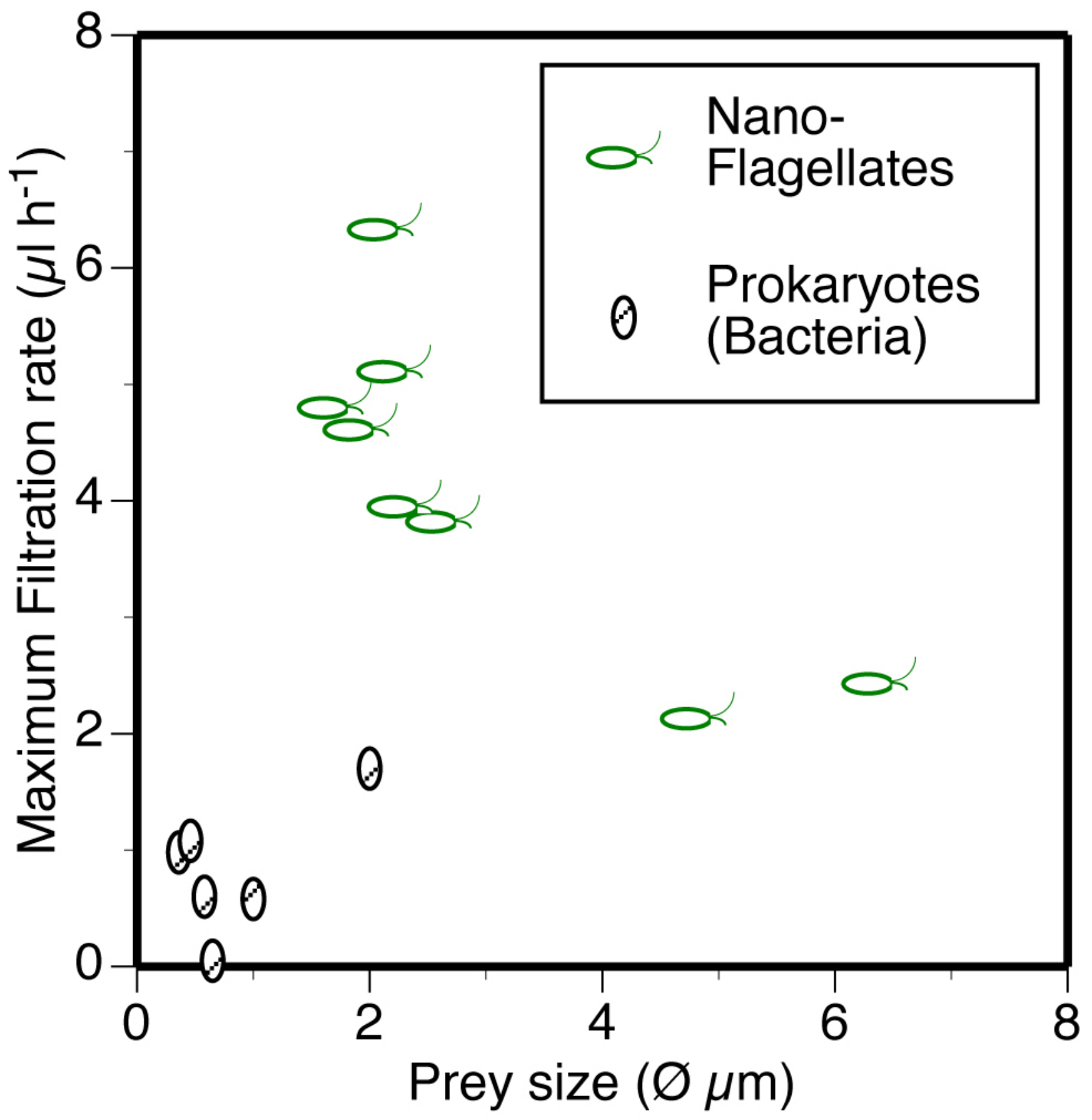

Fig 4 


\section{$\otimes \quad \mathrm{P}$ excr ( $\mu \mathrm{g} \mathrm{P}$ per Cell per $\mathrm{h})$ \\ $\odot \quad \mathrm{N}$ excr $(\mu \mathrm{g} \mathrm{NH} 4-\mathrm{N}$ per cell per $\mathrm{h})$}

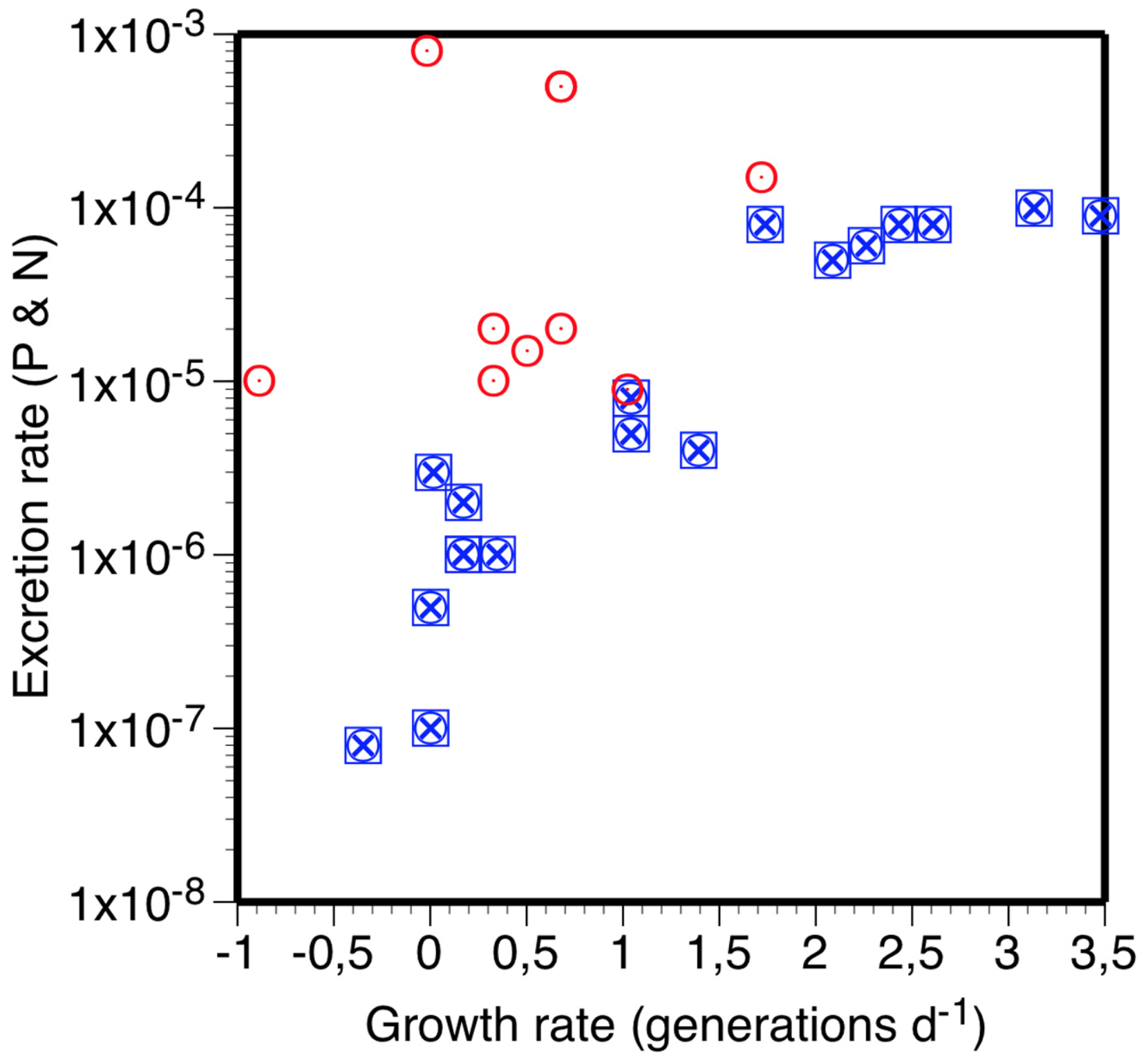

Fig 5 


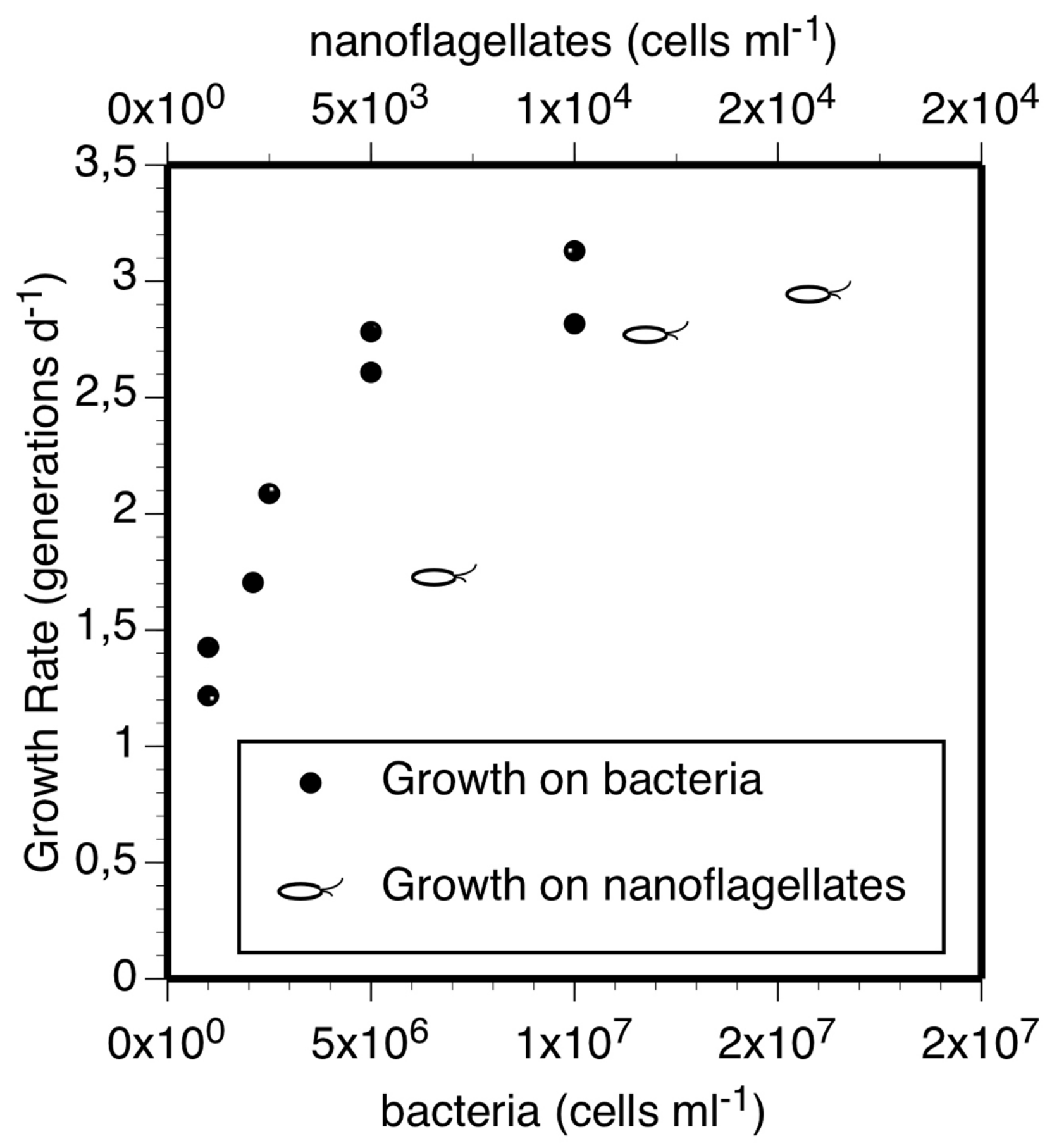

Fig 6 


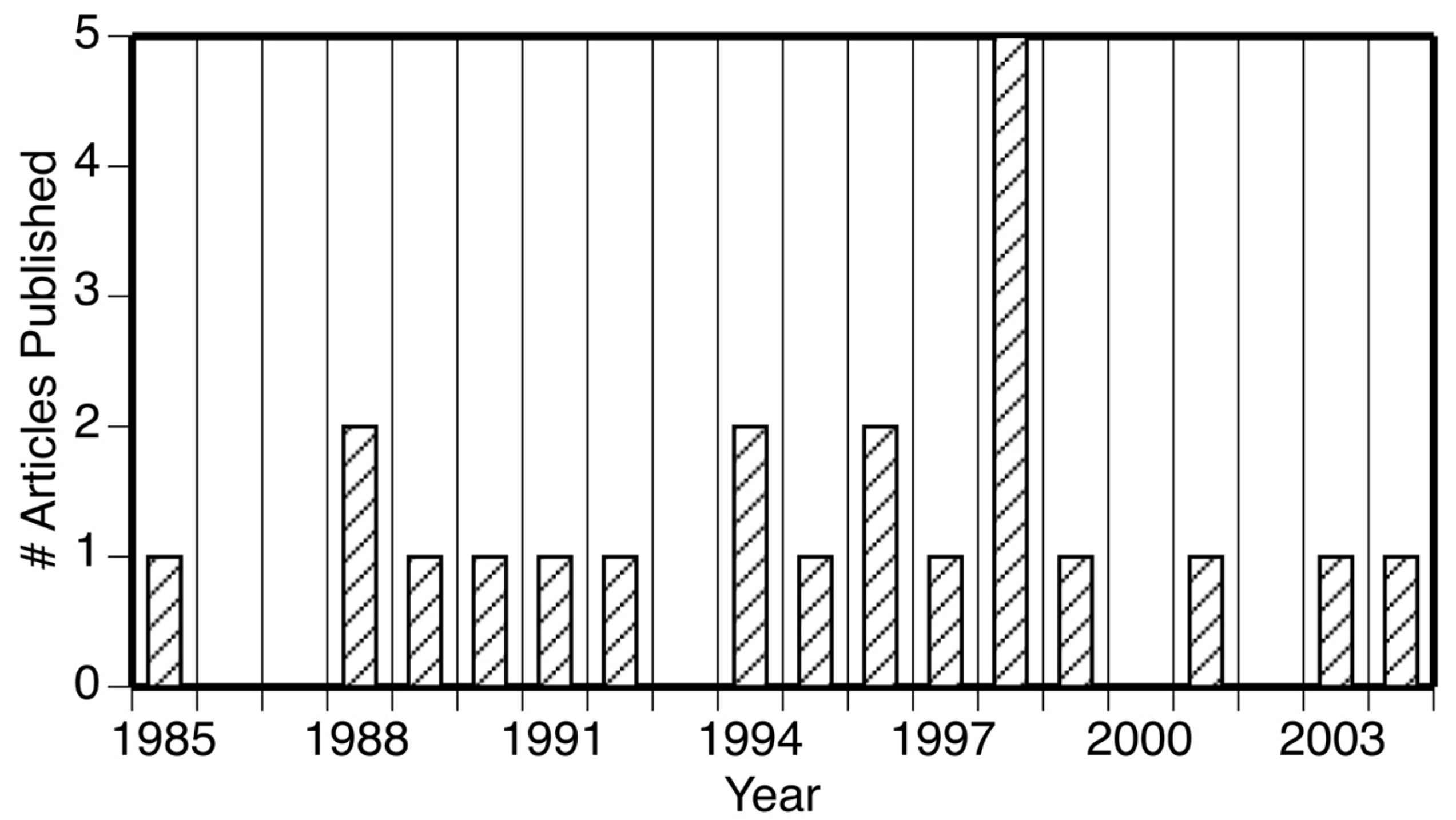

Fig 7 
linking $\frac{\text { के }}{\bar{J} \text { onauplii }} \begin{gathered}\text { sulcatum } \\ \text { response }\end{gathered}$ acids Effects Factors grazing Acartia essential grazing $\frac{\pi}{0}$ rate provides dietary evolution insights analysis ecology feasibility

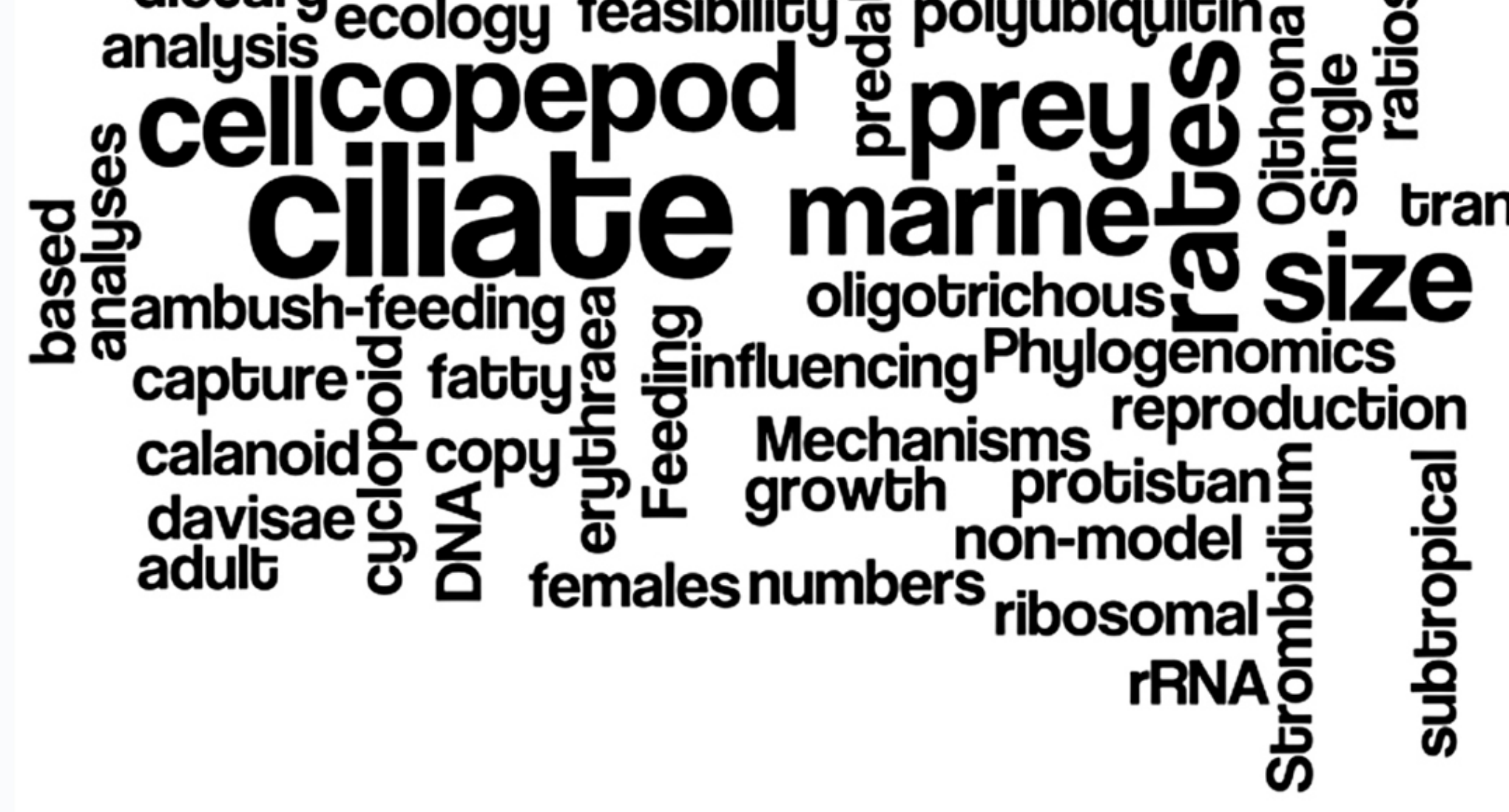




\section{Supplemental File}

\section{Chronological List of Studies employing Strombidium sulcatum from}

Villefranche-sur-Mer (\#) = citations Google Scholar, June 192018

\section{5}

Rivier, A., Brownlee, D.C., Sheldon, R.W., Rassoulzadegan, F., 1985. Growth of microzooplankton: A comparative study of bactivorous zooflagellates and ciliates. Mar. Microb. Food Webs., 1, 51-60. (115)

\section{8}

Fenchel, T., Jonsson, P.R., 1988. The functional biology of Strombidium sulcatum, a marine oligotrich ciliate (Ciliophora, Oligotrichina). Mar. Ecol. Prog. Ser., 48, 115. (131)

Sherr, B. F., Sherr, E. B., \& Rassoulzadegan, F. (1988). Rates of digestion of bacteria by marine phagotrophic protozoa: temperature dependence. Applied and Environmental Microbiology, 54(5), 1091-1095. (188)

\section{9}

Wiadnyana, N. W., Rassoulzadegan, F. 1989. Selective feeding of Acartia clausi and Centropages typicus on microzooplankton. Mar. Ecol. Prog. Ser., 53, 37-45. (141)

\section{0}

Bernard, C., \& Rassoulzadegan, F., 1990. Bacteria or microflagellates as a major food source for marine ciliates: possible implications for the microzooplankton. Mar. Ecol. Prog. Ser., 64, 147-155. (167)

\section{1}

Ferrier, C., Rassoulzadegan, F., 1991. Density-dependent effects of protozoans on specific growth rates in pico- and nanoplanktonic assemblages. Limnol Oceanogr., 36, 657-669. (36)

\section{2}

Stramski, D., Rassoulzadegan, F., Kiefer, D.A., (1992). Changes in the optical properties of a particle suspension caused by protist grazing. J. Plankton Res., 14, 961-977. (12)

1994

Allali, K., Dolan, J., \& Rassoulzadegan, F., 1994. Culture characteristics and orthophosphate excretion of a marine oligotrich ciliate, Strombidium sulcatum, fed heat-killed bacteria. Mar. Ecol. Prog. Ser., 105, 159-165. (25)

Ferrier-Pages, C., Rassoulzadegan F., 1994. N remineralization in planktonic protozoa. Limnol. Oceanogr., 39, 411-419. (41) 


\section{5}

Dolan, J. R., Thingstad, T. F., Rassoulzadegan, F., 1995. Phosphate transfer between microbial size-fractions in Villefranche Bay (NW Mediterranean Sea), France in autumn 1992. Ophelia, 41, 71-85. (53)

\section{6}

Christaki, U., Belviso, S., Dolan, J. R., Corn, M., 1996. Assessment of the role of planktonic copepods and ciliates in the release to solution of DMSP in the N. W. Mediterranean Sea. Mar. Ecol. Prog. Ser. 141, 119-127. (61)

Perez, M. T., Dolan, J. R., Rassoulzadegan, F., Mostajir, B., 1996. Predation on marine picoplankton populations examined with an 'add-in'approach. J. Plankton Res., 18, 635-641. (12)

\section{7}

Dolan, J. R ., Simek, K., 1997. Processing of ingested matter in Strombidium sulcatum, a marine ciliate. Limnol Oceanogr., 42,393-397. (41)

\section{8}

Caparroy, P., Pérez, M. T., Carlotti, F., 1998. Feeding behaviour of Centropages typicus in calm and turbulent conditions. Mar. Ecol. Prog. Seri., 168, 109-118. (55)

Christaki, U., Dolan, J. R., Pelegri, S., Rassoulzadegan, F., 1998. Consumption of picoplankton-size particles by marine ciliates: Effects of physiological state of the ciliate and particle quality. Limnol. Oceanogr., 43, 458-464. (105)

Mostajir, B., Bustillos-Guzmàn, J., Claustre, H., \& Rassoulzadegan, F., 1998. Pigment dynamics associated with the grazing of a ciliate and a flagellate feeding on a cyanobacterium. Oceanol. Acta, 21, 581-588. (8)

Ferrier-Pagès, C., Karner, M., Rassoulzadegan, F., 1998. Release of dissolved amino acids by flagellates and ciliates grazing on bacteria. Oceanol. Acta, 21, 485494. (40)

Pelegri, S. P., Christaki, U., Dolan, J., \& Rassoulzadegan, F., (1998). The use of Echerichia coli as food source for protozoa in excretion experiments: preliminary results. Rapp Comm Int Mer Medit, 35, 358-359. (2)

1999

Christaki, U., Jacquet, S., Dolan, J. R., Vaulot, D., \& Rassoulzadegan, F., 1999. Growth and grazing on Prochlorococcus and Synechococcus by two marine ciliates. Limnol. Oceanogr., 44, 52-61. (156)

\section{1}

Bonnet, D., Carlotti, F., 2001. Development and egg production in Centropages typicus (Copepoda: Calanoida) fed different food types: a laboratory study. Mar. Ecol. Prog. Ser., 224, 133-148. (79) 


\section{3}

Dolan J. R., Sall N., Metcalfe A., Gasser B., 2003. Effects of turbulence on feeding and growth in a marine oligotrich ciliate. Aquat. Microb. Ecol. 31, 183-192. (35)

2004

Mari, X., Rassoulzadegan, F., 2004. Role of TEP in the microbial food web structure. I. Grazing behavior of a bacterivorous pelagic ciliate. Mar. Ecol. Prog. Ser., 279, 13-22. (19)

\section{Recent articles (2009-2017) using Strombidium sulcatum cultures not those of Villefranche}

Fu, R., \& Gong, J., 2017. Single cell analysis linking ribosomal (r) DNA and rRNA copy numbers to cell size and growth rate provides insights into molecular protistan ecology. J. Euk. Microbiol., 64, 885-896

Chen, X., Zhao, X., Liu, X., Warren, A., Zhao, F., Miao, M., 2015. Phylogenomics of non-model ciliates based on transcriptomic analyses. Protein Cell, 6, 373-385.

Yang, J., Löder, M.G.J., Boersma, M., Wiltshire, K.H. 2015. Factors influencing the grazing response of the marine oligotrichous ciliate Strombidium cf. sulcatum. Aquat. Microb. Ecol., 74, 59-71.

Saiz, E., Griffell, K., Calbet, A., Isari, S., 2014. Feeding rates and prey: predator size ratios of the nauplii and adult females of the marine cyclopoid copepod Oithona davisae. Limnol. Oceanogr., 59, 2077-2088.

Liu, X., Shi, F., Gong, J., 2013. Variations and evolution of polyubiquitin genes from ciliates. Eur. J. Protistol., 49, 40-49.

Chen, M., Liu, H., Chen, B., 2012. Effects of dietary essential fatty acids on reproduction rates of a subtropical calanoid copepod, Acartia erythraea. Mar. Ecol. Prog. Ser., 455, 95-110.

Kiørboe, T., Andersen, A., Langlois, V. J., Jakobsen, H. H., Bohr, T., 2009.

Mechanisms and feasibility of prey capture in ambush-feeding zooplankton. Proc. Nat. Acad. of Sci. (USA), 106, 12394-12399. 